\title{
Morphology of the larval shell of three oyster species of the genus Crassostrea Sacco, 1897 (Bivalvia: Ostreidae)
}

\author{
Christo, SW. ${ }^{\mathrm{a} *}$, Absher, TM. ${ }^{\mathrm{b} *}$ and Boehs, G. $^{\mathrm{c} *}$

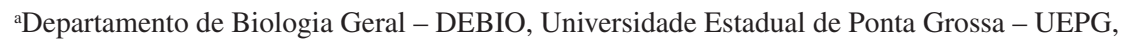 \\ Rua Barão de Monte Alegre, 361, CEP 81540-200, Curitiba, PR, Brazil

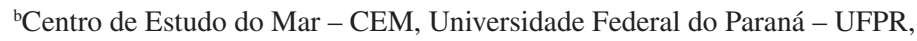 \\ CEP 83255-000, Pontal do Sul, PR, Brazil \\ 'Departamento de Ciências Biológicas - DCB, Universidade Estadual de Santa Cruz - UESC, \\ CEP 45650-900, Ilhéus, BA, Brazil \\ *e-mail: swchristo@onda.com.br, tmabsher@ufpr.br, gboehs@uesc.br \\ Received July 20, 2009 - Accepeted September 18, 2009 - Distributed August 31, 2010
}

(With 8 figures)

\begin{abstract}
In this study we describe the morphology of the larval shell of three oyster species of Crassostrea genus. Two species, C. rhizophorae and C. brasiliana, are native to the Brazilian coast, and C. gigas is an introduced species. Samples of laboratory reared larvae, obtained through artificial fertilisation, were collected at intervals during the cultivation process for analysis using Scanning Electron Microscopy (SEM). Prodissoconch morphology was observed in relation to the presence, position, form and number of teeth in the three larval stages: D-shaped larva, umbo larva and pediveliger. Characteristic of D-shaped larvae of C. rhizophorae was the total absence of teeth in the provinculum area while C. brasiliana and C. gigas had two anterior and two posterior teeth in each valve. In the umbo larval phase, the three species had the same number of teeth in each valve: two posterior and two anterior teeth in the right valve and three posterior and three anterior in the left valve. In the pediveliger stage the three species could be differentiated by the number of anterior teeth of the right valve: C. rhizophorae had two teeth, $C$. brasiliana one tooth and C. gigas three teeth.
\end{abstract}

Keywords: Crassostrea, oyster larvae, prodissoconch, shell morphology.

\section{Morfologia de conchas larvais de três espécies de ostras do gênero Crassostrea Sacco, 1897 (Bivalvia: Ostreidae)}

\begin{abstract}
Resumo
Neste estudo, foi descrita a morfologia das conchas larvais de três espécies de ostras do gênero Crassostrea. Duas espécies, $C$. rhizophorae e $C$. brasiliana, são nativas da costa brasileira e $C$. gigas é uma espécie introduzida. Amostras de larvas produzidas em laboratório através de fertilização artificial foram coletadas em intervalos durante o processo de cultivo para análises dos número de dentes nos três estágios larvais: larva D, umbo e pediveliger. As larvas D de C. rhizophorae caracterizaram-se pela total ausência de dentes na área do provinculum, enquanto C. brasiliana e C. gigas apresentaram dois dentes anteriores e dois posteriores em cada valva. Na fase umbo, as três espécies apresentaram o mesmo número de dentes em cada valva: dois dentes anteriores e dois posteriores na valva direita; e três dentes posteriores e três anteriores na valva esquerda. Na fase pediveliger, as três espécies se diferenciaram pelo número de dentes anteriores na valva direita: C. rhizophorae apresentou dois dentes; C. brasiliana, um dente; e C. gigas, três dentes.
\end{abstract}

Palavras-chave: Crassostrea, larvas de ostra, prodissoconcha, morfologia. 


\section{Introduction}

Oysters are bivalve mollusks, belonging to the family Ostreidae, with wide geographical distribution. The genus Crassostrea Sacco, 1897 comprises species of great economic importance. They occur from estuary zones of low salinity, as in the case of the Brazilian species $C$. rhizophorae (Guilding, 1828) and C. brasiliana (Lamarck, 1819), to areas of normal marine salinities, including the Japanese oyster $C$. gigas (Thunberg, 1793) which is widespread and cultivated in several countries (Malouf and Breese, 1977). The presence of two species of oysters of the Crassostrea genus on the Paraná Coast (Brazil), has been confirmed by various authors (Absher, 1989; Ignácio et al., 2000; Lazoski, 2004) through comparative studies based on aloenzimes analysis, though $C$. rhizophorae and $C$. brasiliana, are still considered by some authors (e.g. Rios, 2009) as synonymous. Crassostrea rhizophorae, inhabits the intertidal area, fastened to the aerial roots of mangrove reaching at the most $8-9 \mathrm{~cm}$ in height (Nascimento, 1983). This species occurs from the Caribbean waters to Uruguay (Rios, 2009). Crassostrea brasiliana may reach more than $25 \mathrm{~cm}$ in height (Absher, 1989). Larvae of both species are present at the same time in plankton samples from the area, since these species reproduce throughout the year (Absher, 1989; Absher et al., 2000).

The dimension of the larval shell of oysters, its general form, the prominence and form of the umbo during the planktonic period, and the relationships between the length and height of the provinculum, are important diagnostic characteristics (Dinamani, 1976; Waller, 1981; Hu et al., 1993; Carriker, 1996; Eble and Scro, 1996). Thus, detailed studies of the morphological characteristics of the larval shell allow the description and differentiation of congeneric species.

Detailed studies of the larval shell using Scanning Electron Microscopy (SEM) supply information about the modifications that occur in the provinculum of the prodissoconch in the course of larval and post-larval development. It is important to differentiate con-generic larvae of Ostreidae and of larvae of other bivalve families, when isolated in planktonic samples (Webb, 1987; Fuller et al., 1989; Hu et al., 1993; Kimura and Sekiguchi, 1994; Monteiro-Ribas et al., 2006). The first larval stage after the trocophore of bivalves is characterised by the beginning of calcification and the formation of a shell-prodissoconch I (PI) followed by the prodissoconch II (P-II), with different structures characteristic of each species (Christo and Absher, 2008). Micrography produced using SEM of the larval shells of oysters can provide important information about the modifications of the prodissoconch. The objective of this study was to compare the morphological characteristics of the larval shells between trocophore and pediveliger of C. rhizophorae, C. brasiliana and C. gigas, as well as to determine diagnostic characters for the identification of their larvae.

\section{Material and Methods}

The comparative description of the provinculum of the larval shell was based on disjointed valves of the three oyster species reared in the laboratory from artificial fertilisation. The parent specimens of $C$. rhizophorae and of $C$. brasiliana were obtained from the coast of the State of Paraná and of C. gigas from Santa Catarina State (South Brazil). Specimens with full and/or partially filled gonads were used for the rearing experiments. Reproductive cells were stripped from clean individuals of two females for each male. Rearing techniques were adapted from Absher et al. (2000). During the whole cultivation process, samples of larvae were collected and preserved in ethanol $70 \%$ and later transferred to a solution of sodium hydroxide (5-10\%) and left for approximately 48 hours, before the separation of the valves. After this period, the shells were washed with $90 \%$ ethanol, dried at $65^{\circ} \mathrm{C}$ for about 10 minutes and mounted on adhesive ribbon in metallic supports, for metallisation through vaporisation (i.e., sputter coating) with gold for the exam of the larval shell in the scanning electron microscope. Observations and electron micrographs were performed and obtained on Philips XL - 30 equipment of LAC/CNMT - COPEL. Height measurements (dorso-ventral axis) of the larvae were obtained during the first phase of each larval stage.

\section{Results}

In the phase of D-shaped larva, the prodissoconch I area of the hinge was a completely straight line in all the species. The height of the larvae in that phase varied from $51 \mu \mathrm{m}$ (C. rhizophorae) to $73 \mu \mathrm{m}$ (C. gigas). A total absence of teeth in this area of the right and left valves characterises the $C$. rhizophorae larvae (Figure 1). Crassostrea brasiliana larvae presented in the hinge line two rectangular teeth of the same size in the anterior and posterior extremities of the right and left valves (Figure 2a-2b, respectively), as did C. gigas (Figure 3).

Umbo larvae were characterised by a sloping form in the direction of the posterior end of the shell, due to the development of the left valve umbo in the three species. The right valve of $C$. rhizophorae larvae of $115 \mu \mathrm{m}$ height had two anterior and of two posterior teeth of the same size (Figure 4a). Three anterior and three posterior teeth were developed in the left valve, and the central tooth was more conspicuous than the others (Figure 4b). The two cavities observed in the provinculum of the right valve correspond to the fitting of the teeth of the left valve. Crassostrea brasiliana larval shells of $116 \mu \mathrm{m}$ in height developed, as described by Absher et al. (2000), two anterior and two posterior teeth of the same size in the right valve and three cavities for the fitting of the left valve teeth. And the left valve showed three anterior and three posterior teeth, with the anterior and posterior distal teeth smaller than the central tooth. Larvae of $C$. gigas of $152 \mu \mathrm{m}$ in height had 

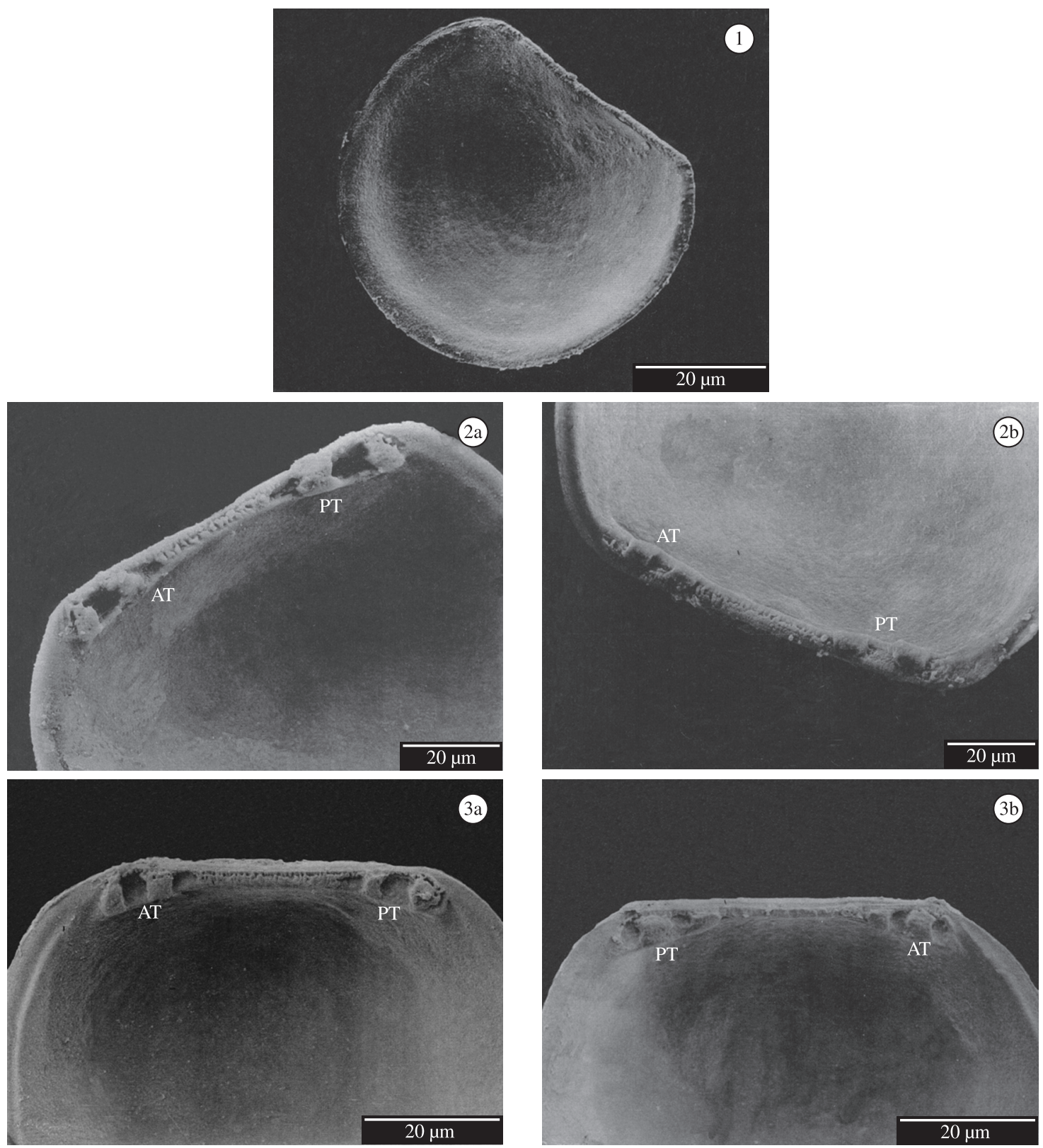

Figure 1-3. SEM micrography of larval shells of oysters in D-shaped Stage. 1) C. rhizophorae, indicating the absence of teeth in the provinculum; 2) C. brasiliana, characterised by anterior teeth (AT) and posterior teeth (PT); 3) C. gigas, with anterior teeth (AT) and posterior teeth (PT). a) right valve; b) left valve.

two anterior and two posterior teeth and three cavities in the right valve, corresponding to the fitting of the teeth of the left valve (Figure 5a). This species was characterised by the presence of three anterior and three posterior teeth in the left valve, with the central tooth more conspicuous than the distal teeth (Figure 5b).

During the pediveliger phase, when the larval shells reach a height of more than $300 \mu \mathrm{m}$, on average, except in C. gigas, a strong curvature of the umbo develops on the hinge towards the posterior end, hiding the posterior teeth of the left valve. Larvae of $C$. rhizophorae with height of $337 \mu \mathrm{m}$ presented two anterior teeth in the right valve (Figure 6a) and one anterior tooth in the left valve (Figure 6b). Crassostrea brasiliana, with height of 390 $\mu \mathrm{m}$, was characterised by the presence of one anterior tooth in the right valve (Figure 7a) and two anterior teeth in the left valve (Figure 7b); while $C$. gigas larvae, with a height of $379 \mu \mathrm{m}$, presented three and two anterior teeth in the right and left valves, respectively (Figure 8a-8b).

Table 1 summarises the measurements of the larval stages and the differences in the provinculum area in teeth number of the three species studied, in all phases of larval growth. 

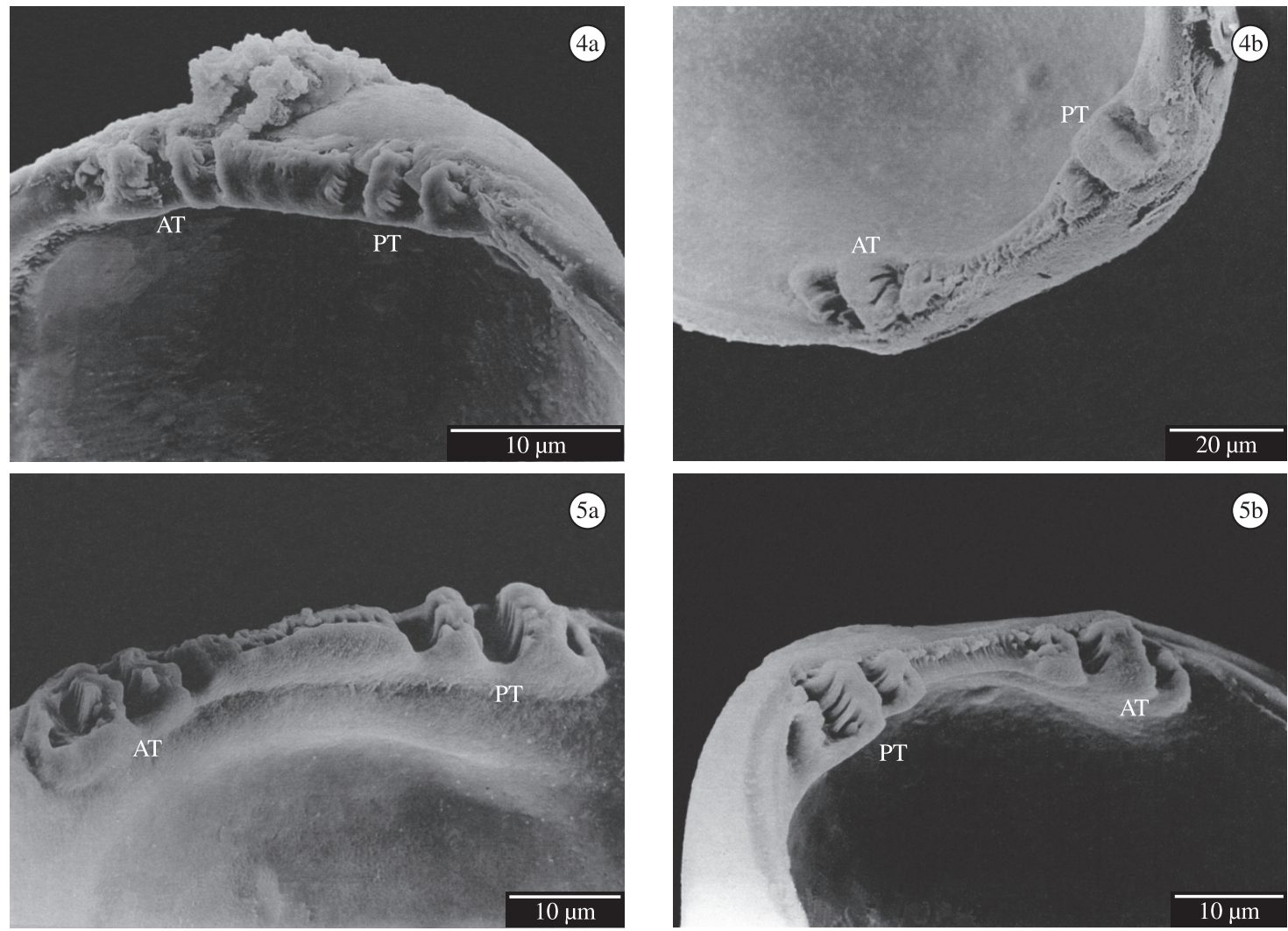

Figure 4-5. SEM micrography of larval shells of oysters in umbo Stage. 4) C. rhizophorae; 5) C. gigas. a) right valve; b) left valve; AT - anterior teeth; PT - posterior teeth.

\section{Discussion}

The morphology of the proviculum area of the three species of oysters, reported in this paper, is an important auxiliary tool for the identification of larvae in plankton samples. It should also be of use in confirming the success of laboratory produced oyster larvae from parents of uncertain identification.

The straight-hinged D-shaped shell of $C$. rhizophorae larvae can be identified by the total absence of teeth in the provinculum area, while larvae of $C$. brasiliana and C. gigas are indistinguishable, because of the presence of the same number of teeth in each extremity of the provinculum of both valves.

The umbo area of larvae larger than $110 \mu \mathrm{m}$, showed a strong growth of the umbo above the level of the hinge, curved towards the posterior direction - Opistogiro. This characteristic, reported by Dinamani (1976) for $C$. gigas, $C$. angulata and $C$. virginica and by Ver (1986) for $C$. iredalei, is only observed in Crassostrea larvae. In this phase of larval development, in $C$. brasiliana and $C$. gigas, a third distal tooth was observed to form in both extremities of the left valve. However there is no differentiation among the three studied species, as to the number, forms and size of the teeth in the provinculum area, in the umbo phase. The left valve of all the species presents three teeth, with the middle teeth more conspicuous than the distals. The variation observed in the length of the provinculum of the left valve, larger than the right valve, for the studied species is a consequence of the appearance of the distal teeth in the left valve. This increase in the length of the provinculum from this larval phase was also observed by Hu et al. (1993).

During the pediveliger stage, when the larvae reach a height above $300 \mu \mathrm{m}$, the posterior teeth of the left valve disappear in consequence of a new shell deposit in the umbo area and the "turn" of this toward the posterior direction. This reduction of the teeth in the posterior area, common in species of Crassostrea (Dinamani, 1976; Hu et al., 1993) was observed in this study, in $C$. rhizophorae larvae of $337 \mu \mathrm{m}$, in C. brasiliana of $390 \mu \mathrm{m}$ and in $C$. gigas of $379 \mu \mathrm{m}$ height. The anterior teeth of the left valve and of the right valve are present and vary in number among the studied species. The posterior teeth of the right valve disappear due to the absence of the teeth of the left valve.

Thus, the results of the comparative studies of the morphology of the prodissoconch of $C$. rhizophorae, $C$. brasiliana and $C$. gigas, indicated in D-shaped larvae the absence of teeth in the provinculum only in $C$. rhizophorae, and that in the umbo larval phase the same number of teeth were observed in the three studied species. Larvae in the pediveliger stage present different numbers of teeth in the right valve, allowing the identification of the three species in this stage. 

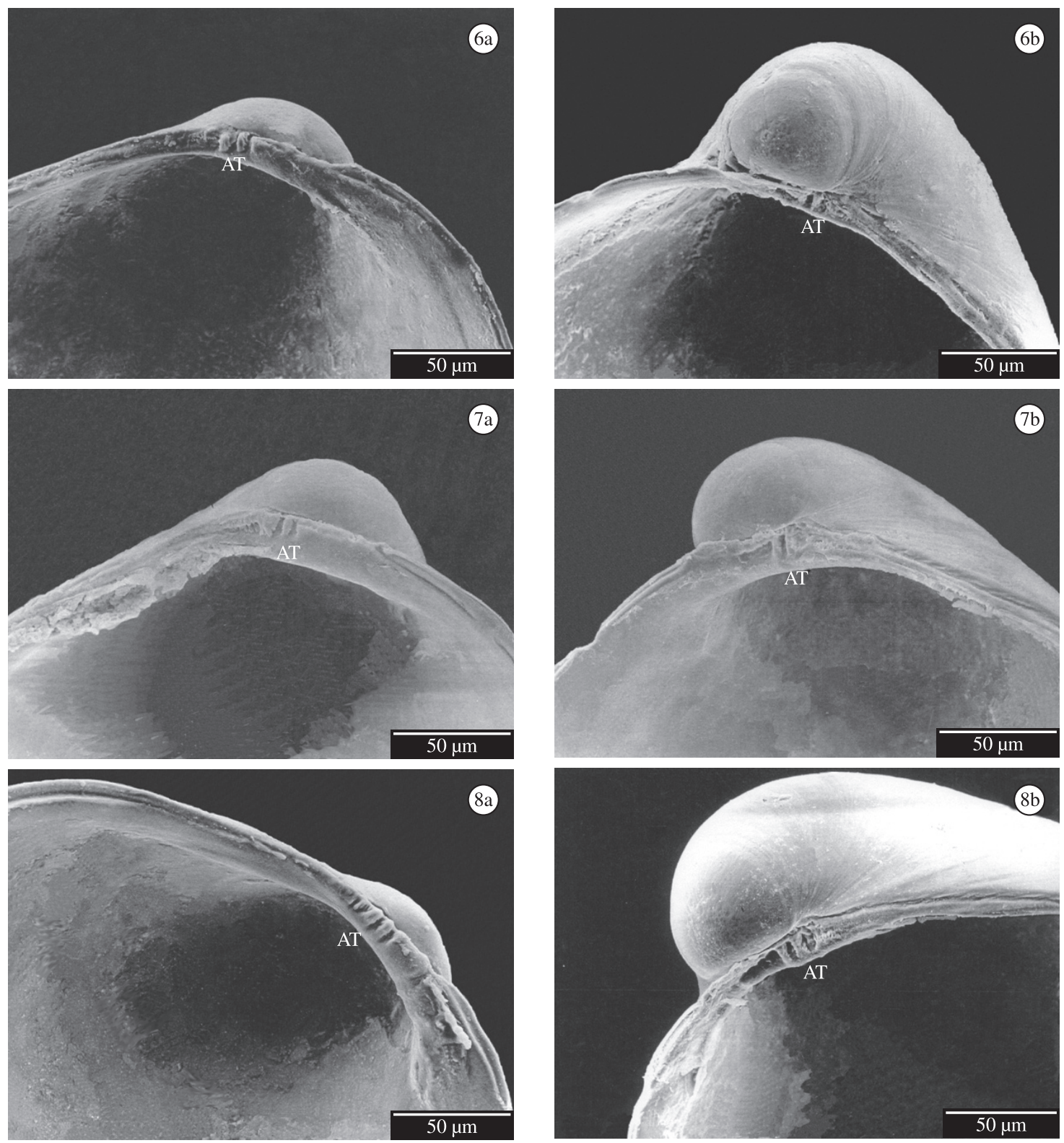

Figure 6-8. SEM micrography of larval shells of oysters in pediveliger Stage. 6) C. rhizophorae; 7) C. brasiliana; 8) C. gigas. a) right valve; b) left valve; AT - anterior teeth; PT - posterior teeth.

Table 1. Number of teeth and mean height and length of different stages of larval growth of the three species of oysters.

\begin{tabular}{|c|c|c|c|c|c|c|}
\hline \multirow[t]{3}{*}{ Larval stage } & \multicolumn{4}{|c|}{ Number of teeth in the provinculum } & \multirow[t]{3}{*}{ Species } & \multirow{3}{*}{$\begin{array}{c}\text { Mean height } \\
(\mu \mathrm{m}) \pm \mathrm{SD} \\
\mathbf{n}=\mathbf{3 0}\end{array}$} \\
\hline & \multicolumn{2}{|c|}{ Right valve } & \multicolumn{2}{|c|}{ Left valve } & & \\
\hline & Anterior & Posterior & Posterior & Anterior & & \\
\hline \multirow{3}{*}{ D - larvae } & 0 & 0 & 0 & 0 & C. rhizophorae & $51 \pm 4$ \\
\hline & 2 & 2 & 2 & 2 & C. brasiliana & $56 \pm 0.5$ \\
\hline & 2 & 2 & 2 & 2 & C. gigas & $73 \pm 3.6$ \\
\hline \multirow[t]{3}{*}{ Umbo } & 2 & 2 & 3 & 3 & C. rhizophorae & $115 \pm 3.7$ \\
\hline & 2 & 2 & 3 & 3 & C. brasiliana & $116 \pm 4.4$ \\
\hline & 2 & 2 & 3 & 3 & C. gigas & $152 \pm 10$ \\
\hline \multirow[t]{3}{*}{ Pediveliger } & 2 & 0 & 0 & 1 & C. rhizophorae & $337 \pm 16$ \\
\hline & 1 & 0 & 0 & 2 & C. brasiliana & $390 \pm 7.2$ \\
\hline & 3 & 0 & 0 & 2 & C. gigas & $379 \pm 12$ \\
\hline
\end{tabular}


Acknowledgements - The authors thank CAPES and UEPG for the financial support, the Zooology/UFPR Postgraduation course, Dr. Maurício P. Cantão, of the Development and Research Centre - LAC/CNMT (COPEL), for his support in several sessions of electronic microscopy, Liliane O. Ceuta, for editing the figures, and especially to Professor Pamela Hallock Muller from the College of Marine Science, University of South Florida, for the English review.

\section{References}

ABSHER, TM., 1989. Populações naturais de ostras do gênero Crassostrea do litoral do Paraná: desenvolvimento larval, recrutamento e crescimento. São Paulo: Universidade de São Paulo. 185 p. [Tese de Doutorado]

ABSHER, TM., VERGARA, EM. and CHRISTO, SW., 2000. Growth and allometry of the larval shell of the brazilian oyster Crassostrea brasiliana (Lamarck, 1819) (Bivalvia: Ostreidae). Ophelia, vol. 53, no. 2, p. 105-112.

CARRIKER, MR., 1996. The shell and ligament. In KENNEDY, VS., NEWELL, RIE. and EBLE, AF. (Eds.). The Eastern Oyster Crassostrea virginica. Maryland: Maryland sea Grant College Park. p. 75-159. (cap. 3)

CHRISTO, SW. and ABSHER, TM., 2008. Crescimento da prodissoconcha de ostras do gênero Crassostrea Sacco, 1897 (Bivalvia, Ostreidae). Boletim do Instituto de Pesca, vol. 34, no. 1, p. 71-77.

DINAMANI, P., 1976. The morphology of the larval shell of Saccostrea glomerata (Gould, 1850) and a comparative study of the larval shell in the genus Crassostrea Sacco, 1897 (Ostreidae). Journal of Molluscan Studies, vol. 42, p. 95-107.

EBLE, AF. and SCRO, R., 1996. General anatomy. In KENNEDY, VS., NEWELL, RIE. and EBLE, AF. (Eds.). The Eastern Oyster Crassostrea virginica. Maryland: Maryland Sea Grant College Park. p. 66-68. (cap. 2)

FULLER, SC. , LUTZ, RA. and POOLEY, A., 1989. Procedures for accurate documentation of shapes and dimensions of larval bivalve shells with scanning electron microscopy. Transactions of the American Microscopical Society, vol. 108, no. 1, p. 58-63.
HU, YP., FULLER, CS., CASTAGNA, M., VRISENHOEK, RC. and LUTZ, RA., 1993. Shell morphology and identification of early life history stages of congeneric species of Crassostrea and Ostrea. Journal of the Marine Biological Association of the United Kingdom, vol. 73, no. 3, p. 471-496.

IGNÁCIO, BL., ABSHER, TM., LAZOSKI, C. and SOLÉ-CAVA, AM., 2000. Genetic evidence of the presence of two species of Crassostrea (Bivalvia: Ostreidae) on the coast of Brazil. Marine Biology, vol. 136, no. 6, p. 987-991.

KIMURA, T. and SEKIGUCHI, H., 1994. Larval and post-larval shell morphology of two Mytilid species Musculista senhousia (Benson) and Limnoperna fortunei kikuchii Habe. Venus: The Japanese Journal of Malacology, vol. 53, p. 307-318.

LAZOSKI, C. , 2004. Sistemática molecular e genética populacional de ostras brasileiras (Crassostrea spp.). Rio de Janeiro: Universidade Federal do Rio de Janeiro. 145 p. [Tese de Doutorado]

MALOUF, RE. and BREESE, WP., 1977. Seasonal changes in the effects of temperature and water flow rate on the growth of juvenile Pacific Oysters, Crassostrea gigas (Thunberg). Aquaculture, vol. 12, p. 1-13.

MONTEIRO-RIBAS, W., ROCHA-MIRANDA, F., ROMANO, RC. and QUINTANILHA, J., 2006. Larval development of Brachidontes solisianus (Bivalvia, Mytilidae), with notes on differences between its hinge system and that of the mollusk Perna perna. Brazilian Journal of Biology, vol. 66, no. 1, p. 109-116.

NASCIMENTO, IA., 1983. Cultivo de ostras no Brasil: problemas e perspectivas. Ciênciae Cultura, vol. 35, no. 7, p. 871-876.

RIOS, EC. , 2009. Compendium of Brazilian Sea Shells. Rio Grande: Evangraf. 668 p.

VER, LMM., 1986. Early development of Crassostrea iredalei (Faustino, 1932) (Bivalvia: Ostreidae), with notes on the structure of the larval hinge. Veliger, vol. 29, no. 1, p. 78-85.

WALLER, TR., 1981. Functional morphology and development of veliger larvae of the European oyster, Ostrea edulis Linné. Smithsonian Contributions to Zoology, vol. 328, 70 p.

WEBB, CM., 1987. Post-larval development of the bivalves Nucula turgida, Venus striatula, Spisula subtruncata and S. elliptica (Mollusca: Bivalvia). Journal of the Marine Biological Association of the United Kingdom, vol. 67, no. 2, p. 441-459. 